\title{
Pleural Biopsy
}

National Cancer Institute

\section{Source}

National Cancer Institute. Pleural Biopsy. NCI Thesaurus. Code C51897.

Removal of a portion of pleural tissue, for microscopic examination. 